\title{
Using the Study Abroad Experience to Augment Preservice Teachers' Practicum
}

\section{Melodie Cook \\ University of Niigata Prefecture}

\section{Howard Brown}

University of Niigata Prefecture

\section{Reference Data:}

Cook, M., \& Brown, H. (2019). Using the study abroad experience to augment preservice teachers' practicum. In P. Clements, A. Krause, \& P. Bennett (Eds.), Diversity and inclusion. Tokyo: JALT.

Preservice training for secondary-school teachers in Japan has been criticized as inconsistent and ineffective and is seen to have little influence on their teaching repertoire. Early career teachers tend to be more strongly influenced by their experiences as students and their observation of senior teachers. However, they lack training in how to effectively observe lessons. In this study, we explored preservice teachers using classroom-observation rubrics while studying abroad as a method to encourage them to observe other teachers' lessons more effectively. Results show that these preservice teachers noted aspects of their teacher's classroom practice including flexibility in the pace and flow of the lesson, techniques for classroom management, and attention to students' individual needs and progress. Results also indicate that the relatively simple intervention, introducing a classroom-observation rubric and encouraging discussion about it, was a catalyst for students to become reflective and critical observers of senior teachers classroom practice.

日本の中等教育向けの教職課程は、一貫性がなく、効果がないと言われている。実践的指導力の養成に与える影響は弱 い。若手教員はむしろ、自身の学生時代の経験や先輩教員の授業観察を通して、より強い影響を受けているようだ。しかし、教

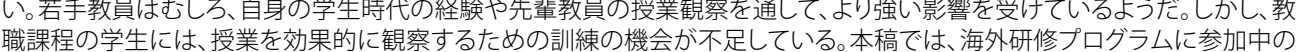
教員志望の学生に、先輩教員の授業を効果的に観察する訪法として授業観察の注意項目を提示しその結果を調查した。研

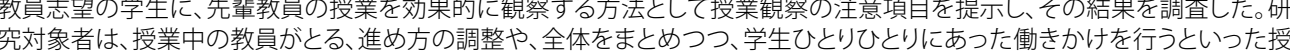
業運営の特徵への気づきがあつた。また、この授業観察時の注意項目を提示し、気づいた点を話し合うといつた比較的単純な 作業によつて、研究対象者が先輩教員の授業をより意識的かつ批判的に観察できるようになった。
D reservice secondary-school English-language teachers in Japan often have insufficient grounding in language-teaching theory and pedagogy (Cook, 2012; Umeda, 2014). When they become practicing teachers, their lessons are heavily influenced by observation of senior teachers and their own experiences as students. In this pilot project, we investigated the influence of a short-term study-abroad experience on prospective teachers' images of language teaching.

\section{Training for Preservice Teachers}

In Japan, preservice secondary-school teachers have two licensing options. They may attend a specialized university program in education and study both educational practice and their discipline, or they may attend a general education program in their discipline supplemented with an elective teachers' licensure program. In either case, the teachereducation curriculum includes law and the legal responsibilities of schools, psychology, education theory, and pedagogy. There is also a mandatory teaching practicum in which they observe classes and conduct lessons (Cook, 2012; Umeda, 2014).

However, preservice preparation in Japan has been criticized as inconsistent and ineffective (Howe, 2005; Umeda, 2014). Howe acknowledged positive results of inservice training for teachers but argued that preservice training is "underdeveloped" (p. 130). Howe also noted a disconnect between university education programs and the reality of secondary-school classrooms, with early in-service training generally ignoring lessons learned at university. For English-language teaching, preservice teachers often lack sufficient grounding in language acquisition theory, teaching methodology and pedagogy, and language testing (Umeda, 2014; Yonesaka, 2004).

The practicum for trainee teachers may compensate for some of these deficiencies. Observation of lessons conducted by experienced colleagues is an invaluable part of training, providing insight into classroom teaching (Fujieda, 2010). However, in Japan, the required practicum is among the shortest in the OECD (OECD, 2014), and 
teacher-licensure programs have been criticized for focusing practicum preparation on formalities rather than substance. Preservice teachers often receive little guidance on how to learn from their practicum (Yonesaka, 1999), and lacking such guidance, studentteachers simply watch senior teachers' lessons. While this can influence their classroom practice (Fujieda, 2010), simple observation is not enough to lead to meaningful learning. Observation needs to be planned and focused in order to be an effective influence on new teachers' (Richards \& Farrell, 2011).

In addition, the same lack of grounding in pedagogy seen in trainee teachers is also seen among teachers who host and supervise practicums (Yonesaka, 2004). Few secondary-school English teachers majored in TEFL or TESL; most are literature majors with very limited training in pedagogy (Browne \& Wada, 1998). Therefore, the practicum may actually serve to perpetuate traditional methods (Cook, 2012) even though current MEXT guidelines call for a more communicative approach (Rapley, 2008)

At the time of the writing of this paper, MEXT's curriculum for teacher licensure is under revision, with changes scheduled for implementation in 2019 (MEXT, 2018); therefore, some of these issues may be at least partially resolved in the near future. In particular, MEXT is calling for more classes on second language acquisition and classroom pedagogy as well as integrated classes where preservice teachers can engage in both communicative and theory-based activities. In terms of the practicum, however the core requirements are not changing. While the new curriculum does allow for an extended practicum during which university students can be part-time volunteer teacher assistants for up to a year, this is not required. Also, because of the considerable logistical challenge for both the university and the hosting school, it is unclear how many programs will actually implement this.

With both preservice education and the practicum being less than ideal, Lortie's (1975) classic notion of the apprentice of observation becomes more important. According to Lortie, teachers' classroom practice is more heavily influenced by their experiences as students than by what they learn in preservice education classes. Crandall (2000) concurred, saying that teachers' "prior learning experiences ... play a powerful role in shaping ... views of effective teaching and learning" (p. 35). The apprenticeship of observation strongly influences how nonnative-speaking teachers of English approach their teaching (da Silva, 2005) and perpetuates a view of language as an object of study, a set of contents, and the notion that there is a single correct method for delivering those contents to students (Tedick, 2009). Thus, exposing preservice teachers to alternate ways of teaching while they are still language students themselves may influence their eventual classroom practice. Study-abroad programs may provide one such source of exposure to these alternate ways.

\section{Study-Abroad Programs for Preservice Teachers}

Study abroad has cultural and linguistic benefits for students including greater acceptance of nonnative varieties of English (Kimura, 2017), more self-reliance (Kirchoff, 2015), and improved self-confidence and self-efficacy (Tanaka \& Ellis, 2003). Longer study-abroad experiences lead to better outcomes (Sasaki, 2011); however, short-term programs are also beneficial. Kimura \& Hayashi (2017) found that a 2-week study-abroad program has positive impacts on motivation, risk-taking, and appreciation of cultural diversity, and Leis (2015) found that even 10 days abroad increased willingness to communicate.

For preservice language teachers, study abroad is also linked to their eventual approach to teaching (Barkhuizen \& Feryok, 2006). In a study of preservice English-language teachers from Hong Kong, Lee (2011) noted how study abroad helped them develop global viewpoints, improve their language abilities, and find new approaches to teaching. Lee also found study abroad introduced preservice teachers to new pedagogical tools, such as different kinds of reading and thinking tasks, and more importantly, showed them how these tools were applied in practical contexts. The preservice teachers in Lee's study also saw new possibilities for building rapport with students and questioned their assumptions about the relationship between students and teachers. However, they were not uncritically accepting of everything they saw while abroad. The "participants were able to question professional practice in the host country and in their home town and appreciate the importance of making adaptations so as to enjoy the respective strengths of the two systems" (p. 17)

\section{The Current Study}

In the current study, we investigated how preservice English language teachers observe senior teachers while studying abroad. University students studying to become secondary school English language teachers joined a study-abroad program, during which they not only participated in ESL classes, but also observed how those classes were taught. The following research questions guided this study:

RQ1: What do preservice teachers notice about second-language teaching during study abroad?

RQ2: Can an observation rubric encourage students to be reflective and critical observers of senior teachers' practice? 


\section{Participants}

The five participants in this study (three females, two males) were preservice secondaryschool English language teachers in the second year of their undergraduate program at a prefectural university. Although they had taken some teaching-related courses as part of a teacher-licensure program, none had yet experienced an in-class practicum. Pseudonyms were assigned to protect students' identities and ensure confidentiality. Thus, in this study, they will be referred as Ms G, Mr. H, Mr. K, Ms M, and Ms O.

Students signed consent forms and were offered the opportunity to opt out of the study, should they have wished to.

The participants studied in one of two intensive 5-week ESL programs in Canada, which consisted of 20-25 hours per week of instruction along with independent study time and sociocultural activities (e.g., visiting a sugar bush, going tubing, visiting museums). The ESL classes were taught by three highly experienced and well-qualified ESL teachers, all of whom possessed graduate degrees in education, had been teaching for an average of 30 years, and had all taught in various countries, including Japan. The participants took part in these ESL classes as students, while at the same time observing their teachers' classroom practice. The students were escorted by the researchers on these programs. Participants in this study represented a minority of students participating in the programs.

\section{Data Collection and Analysis}

Data was collected once before the programme and weekly during the 5-week studyabroad period. Students completed a preprogramme questionnaire about their experiences as students and their impressions of teaching. During the programme, students were given a weekly task (see a summary of topics in Figure 1). These tasks were inspired by those recommended by Richards and Farrell (2011) and Somogyi-Tóth (2012), though they were adapted to simplify them and to remove aspects of the observation rubrics that could be interpreted as the participants evaluating their teachers. Each week, students' written task notes were collected and discussed in a 20-to-30-minute semistructured interview in English with one of the researchers. Students also shared their observations with each other in 30-to-40-minute discussions in Japanese. The interviews and discussions were audio recorded and transcribed by the researchers. Qualitative methods of data analysis were used for this study. Triangulation was done through interviews, observations, and document collection (Creswell, 2009). Where direct quotes from the participants are used below, some are taken from the students' English-language interviews; others were translated by the researchers. The researchers also observed one class in each of the programs; however, these observations were not treated directly as data in this study. Rather, they served to inform the researchers' interpretation of comments made by the participants.

Week Task

1: Preprogramme Questionnaire about images of effective teaching and motivations for becoming a teacher and experiences in language classes

2 Observation rubric - Creating an Atmosphere

3 Observation rubric - Instructional Skills

4

5

Observation rubric - Feedback and Assessment

Free comments

Figure 1. Weekly tasks.

\section{Results}

A brief summary of each of the topics covered in the study is given below, highlighting key observations made by the participants.

\section{Predeparture}

Before the programme began, students answered questions about their experiences in secondary-school English classes and their motivations for becoming a teacher (see Appendix). Students had varying reasons for wanting to become teachers: One was inspired by her parents who are both teachers and three reported being inspired by a particular teacher. Interestingly, this was not always a secondary-school teacher. Mr. $\mathrm{H}$ reported much more positive memories of his teachers at cram school than those in secondary school.

When asked about the kind of teacher they wanted to become, participants noted passion and connection with students as the primary qualities of good teachers. In terms of classroom practice, students valued flexibility, the abilities to answer questions and adapt to individual students' needs, honest feedback, and natural speaking skills. They also noted that effective teachers are confident and enthusiastic about what they are teaching. Interestingly, participants noted that this enthusiasm does not always have to be genuine. According to Ms M, teachers sometimes have to "put on a show." More than in other subjects, "English is irrelevant to most students, so the class itself has to 
be motivating." Other participants expressed similar sentiments, with three noting that the most important characteristic of an effective teacher was creating a comfortable atmosphere where students become excited about learning, can take risks, and feel confident in their own ability to learn English.

When asked about teachers they had had bad experiences with, the students all mentioned teachers who did not treat them as individuals. They also criticized teachers who followed lesson plans or textbooks too faithfully and were not able or willing to adapt the lesson to suit their students.

\section{Week 1: Experiences in Language Classes}

At the end of the participants' 1st week abroad, which was largely an orientation to the programme, they were interviewed about and discussed their experiences as students in language classes at home in Japan. These conversations provided a window into the kinds of teacher that they themselves did not want to become. One thing consistently mentioned was that their secondary-school teachers of English tended to rely heavily on textbooks. More telling, however, was the long list of things they tended not to do, including not making eye-contact with students, not using body language, not giving feedback, not giving praise, not allowing students to practice speaking in class, and not remembering students' names. Because of these things, the participants felt that they could not get close to some teachers, that teachers were scary, and that the atmosphere was hard or severe. Naturally, they did not feel comfortable speaking in front of other students. In addition, because the goals of the classes were not made clear to them, they wondered why they had to study English. Ms M added that it was clear to her that the students' progress mattered less to her teachers than "getting to the end of the chapter on time."

Interestingly, students were more positive in talking about their cram school teachers, particularly because those teachers remembered their names and gave them individualized attention. Ms $\mathrm{O}$ said that if she had not gone to cram school, she would have had trouble in junior high school, and Mr. K said that his grades went up significantly, and thanks to the cram school, he could enter the university of his choice.

\section{Week 2: Creating an Atmosphere}

In the 2nd week, participants were asked to focus on how their teachers created an atmosphere conducive to learning. The observation rubric guided students to notice how their teachers created and managed the class atmosphere (see Appendix).
The participants noted that the teachers started the class each day with personal, individualized attention to each student, greeting them by name and asking about their experiences in Canada thus far, their homework questions, and their relationships with their host families. Participants also mentioned that their teachers gave a lot of praise, not necessarily only for correct answers; they also praised and thanked students for asking questions, helping classmates, or trying, even if unsuccessfully, to contribute to class discussion. This made the students less afraid of making mistakes and encouraged them to be more open to sharing ideas and taking risks. Participants felt that praise and attention from the teachers were spread fairly among the students. Teachers took the time to make comments to each group during or after tasks and asked all students to answer questions or make comments.

On a related note, the participants mentioned the effective way the teachers used space in the classroom, moving around the room so that they were always near students when they talked to them. This made the students more comfortable to ask questions than if the teacher stayed at the front of the room. For these participants, this was evidence that the teachers were trying to lessen the teacher-student social distance. Participants also noticed the teachers' patience and control of the flow of the lesson. The teachers did not push students and there was no pressure to "get through the lesson plan," but at the same time activities started and ended in a timely way and lessons flowed from one task to the next naturally.

\section{Week 3: Instructional Skill}

In Week 3, the observation rubric guided participants to observe specific aspects of classroom practice including how their teacher explained or demonstrated tasks, monitored students' work, and managed groupings and partner changes (see Appendix). One aspect of interest to the participants was the latter; not only did the teachers control groupings and manage partner changes very smoothly, these partner changes did not seem to be random; students were placed in groups of mixed levels and mixed interests, and groupings were changed often enough that each student had a chance to interact with all of their classmates. Although participants appreciated this, they also wondered how possible that would be in their own teaching context, where Japanese secondaryschool students would be hesitant to talk to a variety of partners.

In a theme continuing from Week 2, the participants made a point of mentioning their teachers' patience and attention to individual progress. Activities had a set time limit, but the teachers monitored progress and adjusted the time accordingly. Also, when students were asking or answering a question, teachers were careful to not pressure them, instead 
providing hints and waiting for responses. This monitoring also allowed the teachers to notice when students were having trouble and reteach, offer further explanations, or give hints. In a comment that may be revealing about his experience in high school in Japan, Mr. K said that his teacher in Canada "never looked away from a student that looked confused or uncomfortable," she always noticed when students did not understand and tried to reframe instructions or explanations.

The participants also noted how the teachers explained tasks and activities by making extensive use of examples, demonstrations, and role-plays to ensure that students knew what they were supposed to do. Although these participants had learned a different way to structure classes in Japan, they saw that their Canadian teachers were able to achieve class goals using a variety of methods.

\section{Week 4: Feedback and Assessment}

The topic of Week 4 was feedback and assessment. The participants were guided to observe how the teachers assessed students, gave feedback, and encouraged peer feedback. Participants noticed that the feedback and praise they received encouraged them to be more open and communicative. However, they also noted that the feedback was not always entirely positive. The honest and open feedback they got from their teachers, both positive and corrective, was appreciated. The participants said that they could "see through" the kind of superficial, universally positive "good job" feedback they often received in secondary school in Japan. The honesty they sensed in their Canadian teachers' feedback during this program was an important part of its motivational effect.

The participants also noticed that feedback was not given in isolation. In comments that recalled the lack of flexibility they reported experiencing in secondary school, they praised the Canadian teachers for "breaking away from the lesson plan" to grasp the teachable moment. Feedback often led to minilessons on alternative ways to express an idea, or teachers reteaching a point that students were struggling with. Yet, although students admired this flexibility, they were unsure if they could be as responsive in their own future teaching.

\section{Week 5: Free Observation}

In the last week of the program, participants were asked to give any other comments they wished about their teachers or classes. Some of the points raised in this final week were reiterations of previously noted aspects of the teachers' classroom practice, such as the teachers' patience, flexibility, and attention to individual students' progress. Participants also noted some specific teaching skills such as the use of space, specific honest feedback, and effective explanations and demonstrations of tasks.

However, in this final week, the participants also noted some things about the Canadian teachers' classroom practice that they felt may not be appropriate in their own future classes. First, they noted that their classmates were all highly motivated students who had made the conscious decision to study abroad in Canada. Ms M wondered if these Canadian teachers would be able to teach in the same way with a class of "normal students" in Japan. Second, participants also noticed that Canadian teachers seem to have more freedom and control of their own classroom than is typical in secondary school in Japan. The participants believed that the teachers' ability to respond to individual students' needs, parlay feedback into teachable moments, and reteach confusing points may be related to that freedom and autonomy. They were unsure that they would have the freedom to teach in the same way at home in Japan in "regular classes" in secondary school.

\section{Discussion and Conclusions}

Our results point to two areas of interest: for the students, an awareness of the purpose of language learning, and for the researchers, the use of a simple rubric to focus students' awareness. As to the former, as Mr. K said, "Learning English in Canada is about using English. In Japan, it's about passing the test." With this in mind, participants noticed Canadian teachers' patience, flexibility, and ability to grasp the teachable moment. They also noted the teachers' skill at giving feedback, fostering rapport, motivating learning, and managing groupings. The teachers in this program also used space and movement in a way that was new to the participants.

For the researchers, the relatively simple intervention of giving a weekly observation rubric and offering participants a chance to discuss their observations seemed to be successful. Participants observed their teachers' practice reflectively, noting similarities and, more often, differences between their experience in Canada and their experiences in secondary-school language classes in Japan. They also applied some of what they had learned about pedagogy to their observations, noting how these teachers' practice did not always accord with what they had been taught about effective teaching. Participants also approached their observations critically, noting for example that some of what they saw as effective teaching methodology in the Canadian context might be difficult to apply to their own future classrooms in Japan.

The reflective and critical observations of these students is promising for future applications of the approach used in this pilot study. A similar intervention could help 
preservice teachers become more effective observers of senior teachers during their practicums in Japan, or it could help preservice teachers observe the language classes they enroll in as students on their home campus. We are currently exploring both options as potential follow-up studies.

\section{Bio Data}

Melodie Cook is a professor at the University of Niigata Prefecture. Her current research interests include high-stakes testing, teacher education, and expatriate experiences of schooling in Japan.

Howard Brown is a professor at the University of Niigata Prefecture, where he is coordinator of the English-Medium Studies program. His current research interests relate to the effective implementation of English-medium instruction programs in higher education.

\section{References}

Barkhuizen, G., \& Feryok, A. (2006). Pre-service teachers' perceptions of a short-term international experience programme. Asia-Pacific Journal of Teacher Education, 34(1), 115-134. https://doi. org/10.1080/13598660500479904

Browne, C. M., \& Wada, M. (1998). Current issues in high school English teaching in Japan: An exploratory survey, Language, Culture and Curriculum, 11(1), 97-112. https://doi. org $10.1080 / 07908319808666543$

Cook, M. (2012). Revisiting Japanese English teachers' (JTEs) perceptions of communicative, audiolingual, and grammar translation (Yakudoku) activities: Beliefs, practices, and rationales. Asian EFL Journal, 14(2), 79-98. Retrieved from https://www.asian-efl-journal.com/volume-14-issue-2/

Crandall, J. (2000). Language teacher education. Annual Review of Applied Linguistics, 20, 34-55. https://doi.org/10.1017/S0267190500200032

Creswell, J. W. (2009). Research design: Qualitative, quantitative, and mixed methods approaches (3rd ed.). Thousand Oaks, CA: Sage.

da Silva, M. (2005). Constructing the teaching process from inside out: How pre-service teachers make sense of their perceptions of the teaching of the four skills. TESL-EJ, 9(2). Retrieved from http://www.tesl-ej.org/wordpress/issues/volume9/ej34/ej34a10/

Fujieda, Y. (2010). Exploration of teaching and construction of teacher identity through teaching practicum: A case study of a pre-service Japanese EFL teacher. Kyoai Gakuen Maebashi Kokusai Daigaku Ronshu, 10, 111-123. Retrieved from http://www.kyoai.ac.jp/college/ronshuu/no-10/ fujieda.pdf
Howe, E. (2005). Japan's teacher acculturation: Critical analysis through comparative ethnographic narrative. Journal of Education for Teaching, 31(2), 121-131. https://doi. org/10.1080/02607470500127251

Kimura, D. (2017). Changing orientations to English during English-medium study abroad in Thailand. In P. Clements, A. Krause, \& H. Brown (Eds.), Transformation in language education (pp. 188-194) Tokyo: JALT. Retrieved from http://jalt-publications.org/sites/default/files/pdf-article/ jalt2016-pcp-024.pdf

Kimura, H., \& Hayashi, B. (2017). Back-to-the-future essays aid study abroad gains. In P. Clements, A. Krause, \& H. Brown (Eds.), Transformation in language education (pp. 172-178) Tokyo: JALT. Retrieved from http://jalt-publications.org/sites/default/files/pdf-article/jalt2016-pcp-022.pdf

Kirchoff, C. (2015). Global personnel development through study abroad and study + work abroad. The Language Teacher, 39(3), 9-12. Retrieved from http://jalt-publications.org/sites/default/files/ pdf-article/39.3tlt-art2.pdf

Lee, J. F. K. (2011). International field experience: What do student teachers learn? Australian Journal of Teacher Education, 36(10), 1-22. https://doi.org/10.14221/ajte.2011v36n10.4

Leis, A. (2015). Study abroad and willingness to communicate: A case study at junior high school. The Language Teacher, 39(2), 3-9. Retrieved from http://jalt-publications.org/sites/default/files/ pdf-article/39.2tlt-art1.pdf

Lortie, D. C. (1975). School teacher: A sociological inquiry. Chicago, ll: University of Chicago Press. MEXT. (2018). 平成31年度から新しい教職課程が始まります [A new teachers' licensure curriculum starting in 2019]. Retrieved from http://www.mext.go.jp/a_menu/shotou/kyoin/1414533.htm

OECD. (2014). Education at a glance 2014: OECD indicators. Paris: OECD Publishing. https://doi. org $/ 10.1787 / 888933120252$

Rapley, D. J. (2008). Policy and reality: The teaching of oral communication by Japanese teachers of English in public junior high schools in Kurashiki City, Japan (Unpublished master's thesis). Massey University, Palmerston North, New Zealand. Retrieved from http://mro.massey.ac.nz/ handle/10179/794

Richards, J., \& Farrell, T. (2011). Practice teaching: A reflective approach. Cambridge, England: Cambridge University Press.

Sasaki, M. (2011). Effects of varying lengths of study-abroad experiences on Japanese EFL students' L2 writing ability and motivation: A longitudinal study. TESOL Quarterly, 45(1).

Somogyi-Tóth, K. (2012). Tasks for teaching practice. The Teacher Trainer Journal, (26)3, 7. Retrieved from https://www.tttjournal.co.uk/uploads/File/ttj_plus/Observation\%20Tasks.pdf

Tanaka, K., \& Ellis, R. (2003). Study-abroad, language proficiency, and learner beliefs about language learning. JALT Journal, 25(1), 63-85. Retrieved from https://jalt-publications.org/sites/ default/files/pdf-article/jj-25.1-art3.pdf

Tedick, D. J. (2009). K-12 language teacher preparation: Problems and possibilities. The Modern Language Journal, 93(2), 263-267. https://doi.org/10.1111/j.1540-4781.2009.00860_2.x 
Umeda, K. (2014). The teaching of English in secondary schools in Japan: From curriculum to the classroom (Unpublished doctoral dissertation). University of Waikato, Hamilton, New Zealand. Retrieved from https://hdl.handle.net/10289/8901

Yonesaka, S. (1999). The pre-service training of Japanese teachers of English. The Language Teacher, 23(11), 9-16. Retrieved from https://jalt-publications.org/articles/24555-pre-service-trainingjapanese-teachers-english

Yonesaka, S. (2004). Teaching what, to whom, how, and why: A review of pre-service Japanese EFL teacher beliefs. Hokkai Gakuen University Studies in Culture, 29, 19-40. Retrieved from http:// hokuga.hgu.jp/dspace/handle/123456789/1411

Appendix

Each Week's Focus

\begin{tabular}{|l|l|}
\hline Week & Questions \\
\hline $\begin{array}{l}\text { 1: Information } \\
\text { about the } \\
\text { students/Beliefs } \\
\text { about "good" } \\
\text { teachers }\end{array}$ & $\begin{array}{l}\text { Why did you decide to become an English teacher? } \\
\text { Who was your favourite English teacher in junior high school and } \\
\text { high school? Why? }\end{array}$ \\
$\begin{array}{l}\text { and high school? Why? } \\
\text { In your opinion, what qualities should a good English teacher have? } \\
\text { Based on what you've studied about English education at (home } \\
\text { university) so far, what do you think are the most important things a } \\
\text { teacher should do? } \\
\text { Rank the following characteristics of teachers from 1 (low) to 9 } \\
\text { (high) in order of importance for you: }\end{array}$ \\
$\begin{array}{l}\text { Knowing students' names } \\
\text { Creating a comfortable environment for learning }\end{array}$ \\
$\begin{array}{l}\text { Using different groupings (all class, groups, pairs, individual } \\
\text { work) }\end{array}$ \\
$\begin{array}{l}\text { Being able to speak English } \\
\text { Being able to explain grammar } \\
\text { Having experience overseas } \\
\text { Grading students fairly }\end{array}$ \\
$\begin{array}{l}\text { Having cultural awareness } \\
\text { Using a variety of methods to teach }\end{array}$
\end{tabular}

\begin{tabular}{|l|l|}
\hline 2: Creating an & The teacher begins lessons with an interesting/fun warm-up activity \\
atmosphere & relating to what students are going to learn. \\
& The teacher creates a comfortable environment where learners are \\
willing to take risks using English. & The teacher gives equal attention to learners depending on their \\
need. & The teachers help students see their own accomplishments. \\
& The teacher speaks at an appropriate speed for students. \\
& The teacher uses body language, gestures, and teaching space as \\
& needed. \\
\hline 3: Teaching skill & $\begin{array}{l}\text { The teacher brings the outside world into the classroom (authentic } \\
\text { materials, nontext materials, etc.) } \\
\text { The teacher gives clear instructions including examples or } \\
\text { demonstrations. } \\
\text { The teacher gives students enough time for each activity. } \\
\text { The teachers give students lots of opportunities to practice. } \\
\text { The teacher is flexible and recognizes moments to suddenly teach } \\
\text { something and accepts correct but different answers. } \\
\text { The teacher monitors students during the activity to help them stay } \\
\text { on task. } \\
\text { The teacher reviews what was learned in previous lessons. } \\
\text { The teacher uses a variety of groupings (whole class, small group, } \\
\text { pairs, and individual). } \\
\text { The teacher uses a variety of materials (textbook, prints, audio- } \\
\text { visual, etc.) } \\
\text { The teacher uses all four skills in each class. } \\
\text { The teacher uses technology. } \\
\text { The teacher allows enough time for students to respond to } \\
\text { questions. } \\
\text { The teacher makes expectations for students clear. }\end{array}$ \\
& \\
&
\end{tabular}




\begin{tabular}{|l|l|}
\hline $\begin{array}{l}\text { 4: Correction } \\
\text { and Assessment }\end{array}$ & $\begin{array}{l}\text { In class, the teacher gives helpful feedback on students' questions } \\
\text { and answers. } \\
\text { The teacher gives helpful feedback on homework assignments. } \\
\text { The teacher gives students opportunities to evaluate each other's } \\
\text { work as appropriate. } \\
\text { The teacher explained clearly how students would be graded earlier } \\
\text { in the semester. } \\
\text { The teacher uses various methods to assess students (tests, essays } \\
\text { presentations, etc.) }\end{array}$ \\
\hline 5: Other & $\begin{array}{l}\text { Please write any other free observations about the teacher you have } \\
\text { been observing over the past } 5 \text { weeks. }\end{array}$ \\
\hline
\end{tabular}

